\title{
Can arbuscular mycorrhiza fungi and NPK fertilizer suppress nematodes and improve tuber yield of yam (Dioscorea rotundata 'cv' ewuru)?
}

\section{Gani Oladejo Kolawole a,*, Tunmise Moses Haastrup a, Timothy Ipoola Olabiyi ${ }^{b}$}

a Ladoke Akintola University of Technology, Department of Crop Production and Soil Science, Oyo State, Nigeria

${ }^{\mathrm{b}}$ Ladoke Akintola University of Technology, Department of Crop and Environmental Protection, Oyo State, Nigeria

\section{Article Info}

Received : 03.07 .2017

Accepted : 16.01 .2018

\begin{abstract}
Poor soil fertility and nematodes limit yam tuber yield and quality. Arbuscular mycorrhizal fungi (AMF) and fertilizers may suppress nematodes and improve yam productivity. We evaluated the extent AMF and fertilizer suppressed nematodes and improved yam performance. Tuber weight, mycorrhizal colonization of roots and nematode populations were evaluated with eight treatments; Control (No amendments), 90-50-75, kg N- $\mathrm{P}_{2} \mathrm{O}_{5}-\mathrm{K}_{2} \mathrm{O}$ ha $^{-1}$ (NPK), (AMF) (2g/kg soil), nematodes (5000 juvenile/pot), and their combinations. Tuber weight was higher in NPK+AMF and NPK+nematode treatments than $\mathrm{AMF}+$ nematode. $\mathrm{NPK}+\mathrm{AMF}$ improved tuber weight by $17.5 \%$ and $32 \%$ compared with sole NPK or AMF respectively. Compared with control, nematodes did not reduce tuber weight but, AMF+nematode reduced it by $49.4 \%$. NPK reduced AMF colonization of roots and reduced nematode population on tuber, in roots and soil by $34 \%$, $42.6 \%$ and $41 \%$ respectively. NPK+AMF treatment was superior to either NPK or AMF in improving tuber yield while NPK was superior to AMF in suppressing nematodes in roots, soil, and tuber.
\end{abstract}

Keywords: Arbuscular mycorrhizal fungi, nematodes, Nigeria, mineral fertilizer, root colonization, yam tuber weight.

(C) 2018 Federation of Eurasian Soil Science Societies. All rights reserved

\section{Introduction}

Yams (Dioscorea spp) are tropical plants with large reserve of food in their underground tubers (Okoli and Onwueme, 1986). They are important staple food crops in many parts of West Africa, and are prominent during socio-cultural festivals. Yam represents stored wealth, which can be sold all-year-round by the farmer or marketer because they can be stored relatively for longer duration in comparison with other tropical fresh produce (Aidoo, 2009). White yam, Dioscorea rotundata is indigenous to West Africa and it is an important economic crop in the yam belt zone of West Africa. Nigeria accounted for more than $70 \%$ of the world production of yam (Ekanayake and Asiedu, 2003). Many farm-families depend on the tubers for food, cash, local food security and other traditional uses. In spite of the importance and increased demand for yam tubers, its production and productivity has steadily declined (APMEU, 2001). The steadily declining tuber yields of yam per unit area is caused among other factors by decreasing soil fertility, high labour requirement, problems of pests and diseases. Amongst the various constraints to production of yam, nematode pests are of significant importance (Bridge et al., 2005). Application of fertilizer has been reported to increase yam productivity (Kolawole, 2013). Hence, mineral fertilizer application is considered a quick way of meeting the nutrient requirement of yam.

\footnotetext{
${ }^{*}$ Corresponding author.

Ladoke Akintola University of Technology, Department of Crop Production and Soil Science, PMB 4000, Ogbomoso, 210001, Oyo State, Nigeria

Tel.: +2348037198801

E-mail address: ogkolawole@lautech.edu.ng

e-ISSN: 2147-4249 DOI: $10.18393 /$ ejss.384515
} 
Plant parasitic nematodes have been observed to reduce yield, food quality, market value and sprouting of yam. Reduction of $20-30 \%$ in tuber weight at harvest has been reported (Kwoseh, 2000). Although the use of pesticides to control nematode is feasible and effective, but they are costly, scarce or highly toxic for both the user and the environment, constituting serious health hazards (FAO, 2014). Concerns of the environment, crop production and food safety have made researchers to spur many measures to manage nematode pests on crops. For the control of nematodes in yam production, alternative management practices such as hot water treatment of tubers (Coyne et al., 2007), use of cover crops and chemical fertilizers (Kolawole, 2013) have been explored.

Importance of association of arbuscular mycorrhizal fungi (AMF) with yam for natural soil fertility has been demonstrated (Dare et al., 2012). AMFs are important elements of the soil microflora in agroecosystems, which form a mutualistic symbiosis with most plant species. AMFs have been implicated in increasing the availability and uptake of soil phosphorus and trace elements, thereby enhancing host plant growth (Ceballos et al., 2013). Root colonization by AMF, in general, favors plant development by increasing nutrient uptake, hormonal activity, growth rate and consequently yield (Hart et al., 2014), but is also associated with pathogen suppression (Hol and Cook, 2005). Plant parasitic nematodes may enhance or depress colonization of roots and sporulation of mycorrhizal fungus. Likewise, mycorrhizae may decrease or increase nematode penetration, development and reproduction. Previous studies showed the efficiency of indigenous AMF on yam growth (Tchabi et al., 2016).

The present study aimed at determining the effects of NPK mineral fertilizer, AMF inoculation on the performance of yam planted in plant parasitic nematodes infested soil.

\section{Material and Methods}

The experiment was conducted at the Teaching and Research Farm, Ladoke Akintola University of Technology, Ogbomoso (Lat. $8^{0} 10^{\prime} \mathrm{N}$ : Long. $4^{0} 10^{\prime} \mathrm{E}$ ) Oyo State, Nigeria.

Top soil (0-30 cm depth) was collected randomly with soil auger at the Teaching and Research Farm, Ladoke Akintola University of Technology, Ogbomoso. The soil was bulked, mixed thoroughly, air dried, and sieved through $2 \mathrm{~mm}$ mesh size sieve. Thereafter, the soil was sterilized by autoclaving at $120^{\circ} \mathrm{C}$ and $15 \mathrm{psi}$ for 30 minutes and later air dried for $72 \mathrm{~h}$. Sub sample of the autoclaved soil was collected and taken to the laboratory for plant parasitic nematode bioassay and chemical analyses. The initial chemical properties of the soil (sandy loam in texture; sand $810 \mathrm{~g} \mathrm{~kg}^{-1}$, silt $90 \mathrm{~g} \mathrm{~kg}^{-1}$, and clay $100 \mathrm{~g} \mathrm{~kg}^{-1}$ ) are as follows; $\mathrm{pH}-\mathrm{H}_{2} \mathrm{O}$ ) 6.5, total organic carbon $5.3 \mathrm{~g} \mathrm{~kg}^{-1}$, total nitrogen $0.22 \mathrm{~g} \mathrm{~kg}^{-1}$, Bray P $6.9 \mathrm{mg} \mathrm{kg}^{-1}$, Exchangeable cations: $\mathrm{K} 0.22$, Ca 1.48 and $\mathrm{Mg} 0.96$ in $\mathrm{cmol} \mathrm{kg}^{-1}$.

Thirty kg soil each was weighed into thirty two plastic pots (30-liter volume) perforated at the bottom to prevent water logging and allow good water drainage. The pots were properly labeled.

Eggs of Meloidogyne incognita were extracted from galled roots of Celosia argentea using the method described by Hussey and Barber (1973).

There were eight treatments namely: $90-50-75 \mathrm{~kg} \mathrm{~N}-\mathrm{P}_{2} \mathrm{O}_{5}-\mathrm{K}_{2} \mathrm{O}$ ha-1 (NPK) which is the recommended rate for yam in the zone; Arbuscular Mycorrhizal Fungi (AMF) at the rate of $2 \mathrm{~g} / \mathrm{kg}$ soil; Nematodes (5000 eggs and juveniles per pot); AMF + NPK; AMF + Nematode; NPK + Nematode; NPK + Nematode + AMF; and Control (no fertilizer, AMF and nematode). The experiment was arranged in completely randomized design with four replicates.

Healthy white ware yams (cultivar ' ewuru', popular among farmers) were obtained from the local market, steam sterilized at $50-55^{\circ} \mathrm{C}$ and cut into yam setts under sterile condition. Planting was done by opening holes in the autoclave sterilized soil inside the pots and one 200-300 g yam sett was placed in each hole with the cut surface turned upward at an angle of about $45^{\circ}$ and covered with soil and capped 2 weeks after planting (WAP). Staking began 5 months after planting with $4 \mathrm{~m}$ long bamboo stakes. The pots were manually weeded by hand pulling as at when necessary.

Arbucular Mycorrizal Fungi (AMF) was placed in the planting hole in designated pots at the rate of $60 \mathrm{~g} / \mathrm{pot}$. This inoculum contained soil spores, roots of plants used in propagating the inoculum and hyphae. Two weeks after sprouting of yam, each appropriate pot was inoculated with approximately 5000 eggs and juveniles of Meloidogyne incognita. Inoculation was done by slowly dispensing $5 \mathrm{ml}$ of the previously prepared nematode suspension into holes around the yam plant. NPK compound fertilizer (15 - $15-15$ ) (5 $\mathrm{g} /$ pot $)$ and the excess $\mathrm{N}(1.33 \mathrm{~g} / \mathrm{pot})$ and $\mathrm{K}(0.63 \mathrm{~g} / \mathrm{pot})$ were met using urea and muriate of potash, respectively. The fertilizers were applied in a ring form and lightly incorporated into the soil about $30 \mathrm{~cm}$ 
away from the growing yam at five months after planting.

At 48 WAP, the pots were upturned over polyethylene sheet. The roots and tubers were gently separated and the adhering soils washed off. The tubers were weighed on weighing balance and weight per treatment was recorded. Post harvest soil samples were collected from individual pots for nematode bioassay.

Pin-pie extraction method (Whitehead and Hemming, 1965) was used for root and soil nematode extractions within 3 hours after harvesting of the yam tubers. Nematodes were extracted within 48 hours after tubers were collected from the pots. Modified Baermann technique was used for extraction. Nematodes species were identified by means of morphology and morphometrics coupled with guide by the identification key for agricultural important plant-parasitic nematodes (Mekete et al., 2012).

At final harvest, galls on the yam root and tuber were assessed following the method of Sasser et al. (1984) on $0-5$ rating scale where $0=$ no gall; $1=1-2 \%$ gall; $2=3-30 \%$ gall; $3=31-50 \%$ gall; $4=51-70 \%$ gall and $5=71-100 \%$ gall.

At twelve weeks after sprouting, root samples were collected from designated plants by digging $30 \mathrm{~cm}$ away from the main yam plant to get fine roots. The roots were washed with water and then cut into about $10 \mathrm{~cm}$ long pieces, put inside bottles containing ethanol alcohol, and later transferred to the laboratory for mycorrhizal count. Percentage mycorrhizal colonization of roots was determined by gridline-intersect method (Giovanetti and Mosse, 1980), after clearing the root with $\mathrm{KOH}$ and staining with chlorazol black E (Brundrett et al., 1984).

Data were subjected to analysis of variance (ANOVA) using SAS software (SAS, 2009) and treatment means compared using least significant difference (LSD) at 5\% probability level.

\section{Results}

\section{Plant parasitic nematode bioassay of soil after inoculation}

There was no nematode found in the soil that was examined immediately after sterilization before yam planting.

\section{Yam tuber weight}

Tuber weight was significantly higher in NPK+AMF and NPK+nematode treatments compared with $\mathrm{AMF}+$ nematode treatment which had significantly lowest tuber weight (Table 1). The combined application of NPK and AMF improved yam tuber weight by $17.5 \%$ and $32 \%$ compared with the sole application of NPK or AMF respectively. Inoculation of juvenile nematodes into the soil compared with the control (no nematodes, no fertilizer) had no significant effect on yam tuber weight. However, AMF+nematode treatment reduced tuber weight by $49.4 \%$ compared with the control. Compared with the nematode alone treatment, application of NPK fertilizer in nematode infested soil improved tuber weight by $28.4 \%$ and combined application of NPK fertilizer and AMF only improved tuber weight by $12 \%$. That is, the effect of combined application of NPK fertilizer and AMF on yam tuber weight in nematode infested soil was neither additive nor synergistic.

Table 1. Effects of NPK fertilizer and arbuscular mycorrhizal fungi (AMF) on tuber weight and AMF colonization of yam roots grown in nematode infested soil

\begin{tabular}{lcc}
\hline Treatments & Tuber weight $(\mathrm{kg} /$ pot $)$ & AMF colonization (\%) \\
\hline Control & & Nil \\
NPK alone & 0.85 & Nil \\
AMF alone & 0.70 & 72.5 \\
Nematode (NEM) alone & 0.73 & Nil \\
NPK+AMF & 1.03 & 48.5 \\
AMF+NEM & 0.40 & 65.0 \\
NPK+NEM & 1.02 & Nil \\
NPK+AMF+NEM & 0.83 & 49.3 \\
LSD $_{(0.05)}$ & 0.46 & 4.2 \\
\hline
\end{tabular}

\section{AMF colonization of yam roots}

Significantly highest AMF colonization of yam roots was observed in the AMF treatment followed by $\mathrm{AMF}+$ nematode treatment, while $\mathrm{NPK}+\mathrm{AMF}$ and $\mathrm{NPK}+\mathrm{AMF}+$ nematode treatments had significantly lowest AMF root colonization values (Table 1 ). 


\section{Nematode infestation}

Root gall was significantly higher in the AMF+nematode treatment than for the sole nematode treatment (Table 2). Other treatments were not significantly different from each other. All the treatments had no significant effects on yam tuber gall formation (Table 2).

Table 2. Effects of NPK fertilizer and arbuscular mycorrhizal fungi (AMF) on gall index on roots and tuber and nematode population in soil, root and tuber of yam grown in nematode infested soil

\begin{tabular}{|c|c|c|c|c|c|}
\hline \multirow{2}{*}{ Treatments } & \multirow{2}{*}{$\begin{array}{l}\text { Root gall } \\
\text { index }\end{array}$} & \multirow{2}{*}{$\begin{array}{c}\text { Tuber gall } \\
\text { index }\end{array}$} & \multicolumn{3}{|c|}{ Nematode population (number $\mathrm{L}^{-1}$ ) } \\
\hline & & & Root & Tuber & Soil \\
\hline Nematode alone & 1.3 & 3.7 & 1677 & 831 & 1585 \\
\hline $\mathrm{AMF}+$ Nematode & 2.8 & 2.3 & 1185 & 727 & 1421 \\
\hline NPK+Nematode & 1.8 & 3.0 & 962 & 548 & 933 \\
\hline $\mathrm{NPK}+\mathrm{AMF}+\mathrm{Nematode}$ & 2.0 & 3.0 & 930 & 664 & 1139 \\
\hline $\operatorname{LSD}(0.05)$ & 1.25 & ns & 380 & 200 & 412 \\
\hline
\end{tabular}

Nematode population recorded on yam tuber grown in sole nematode infested soil was significantly more than that recorded for NPK+nematode treatment. That is, application of NPK fertilizer reduced nematode population on yam tuber by 34\% (Table 2). Other treatments were not significantly different from each other.

Yam roots harvested from sole nematode infested soil had significantly highest nematode population than the other treatments which were not significantly different from each other (Table 2). Post harvest soil nematode count was the highest in sole nematode infested soil. Inoculation of AMF in nematode infested soil only significantly reduced post harvest nematode population in yam roots, whereas application of NPK fertilizer significantly reduced post harvest nematode populations in the roots, tubers and soil. Combined application of NPK fertilizer and AMF only significantly reduced nematode population in the roots (Table 2).

\section{Discussion}

Generally, plants with mycorrhizae and nematode parasites yield less than mycorrhizal plants without nematodes and more than non-mycorrhizal plants with nematodes. This was also true in the present study except that the non-mycorrhizal plants with nematodes out yielded plants with mycorrhizae and nematode parasites. The observation in the present study that AMF did not improve yam tuber weight compared with the control is in contrast with previous reports (Odoh and Oluwasemire, 2015; Tchabi et al., 2016). The observation is however similar to the report of Sidibe et al. (2015) for yam. Banuelos et al. (2014) observed that in fertilized plants single inoculation with AMF and nematodes caused plant growth depressions, which were counteracted when AMF and nematode inoculation were combined in Impatiens balsamina plants. This is contrary to what was observed in this study where yam tuber yield of fertilized pots with either AMF or nematode inoculation had the highest weight.

Although AMF generally suppressed nematode population on yam roots, tuber and soil similar to the report of Tchabi et al. (2016), but the effect was not as pronounced as that of the application of NPK mineral fertilizer.

In the present study also, arbuscular mycorrhizal colonization of yam roots was reduced with NPK fertilizer application. This is similar to the observation of Kolawole et al. (2015). High P-supply reduced AMF colonization of maize root (Liu et al., 2016). Isolates of AMF differ in their sensitivity to soil and plant $P$ levels and therefore fertilizer application may alter the activity of the symbiosis (Sylvia and Schenck, 1983). There are contradictory reports on the role of fertilizers in influencing AMF in soil. Many reports indicated a negative influence (Vivekanandan and Fixen, 1991) while a few reported a positive influence of fertilizers on AMF (Kolawole, 2013). Previous studies have however found increased levels of AM fungal inoculum and root colonization rates in low-input as compared with intensive farming systems in the field (Douds et al., 1995).

\section{Conclusion}

The effect of combined application of NPK fertilizer and AMF on yam tuber weight in nematode infested soil was neither additive nor synergistic. AMF was less effective in suppressing nematodes compared with NPK fertilizer. NPK fertilizer reduced the negative effect of nematodes on yam tuber weight; significantly reduced nematode populations in the roots, soil, and on the tuber. Nematodes did not reduce yam tuber weight but reduced tuber quality. 


\section{References}

Aidoo, R., 2009. An analysis of yam consumption patterns in Ghanaian urban communities. The School of Graduate Studies, Kwame Nkrumah University of Science and Technology, Kumasi, Ghana. PhD Thesis. Available at [access date : 03.07.2017]: http://ir.knust.edu.gh/bitstream/123456789/252/1/PhD\%20Thesis\%20Robert\%20Aidoo.pdf

APMEU, 2001. CAYS Report of the Agricultural Projects Monitoring and Evaluation Unit (APMEU). Federal Ministry of Agriculture, Abuja, Nigeria. 22p.

Banuelos, J., Alarcón, A., Larsen, J., Cruz-Sánchez, S., Trejo, D., 2014. Interactions between arbuscular mycorrhizal fungi and Meloidogyne incognita in the ornamental plant Impatiens balsamina. Journal of Soil Science and Plant Nutrition 14(1): 63-74.

Bridge, J., Coyne, D., Kwoseh, C.K., 2005. Nematode parasites of tropical root and tuber crops. In: Plant parasitic nematodes in subtropical and tropical agriculture. 2nd Edition. Luc, M., Sikora, R., Bridge, J. (Eds.). CAB International, Walingford, UK. pp. 221-258.

Brundrett, M.C., Piché, Y., Peterson, R.L., 1984. A new method for observing the morphology of vesicular-arbuscular mycorrhizae. Canadian Journal of Botany 62(10): 2128-2134.

Ceballos, I., Ruiz, M., Fernández, C., Peña, R., Rodriguez, A., Sanders, I.R., 2013. The in vitro mass-produced model mycorrhizal fungus, Rhizophagus irregularis, significantly increases yields of the globally important food security crop cassava. PLOS ONE 8(8): e70633.

Coyne, D., Nicol, J., Claudius-Cole, A., 2007. Practical Plant Nematology: Field and Laboratoty Guide. IITA, Ibadan, Nigeria. 82p.

Dare, M.O., Abaidoo, R., Fagbola, O., Asiedu, R., 2012. Diversity of arbuscular mycorrhizal fungi in soils of yam (Dioscorea spp.) cropping systems in four agroecologies of Nigeria. Archives of Agronomy and Soil Science 59(4): 521-534.

Douds, Jr.D.D., Galvez, G., Junke, R.R., Wagoner, P., 1995. Effect of tillage and farming system upon populations and distribution of vesicular-arbuscular mycorrhizal fungi. Agriculture, Ecosystems and Environment 52(2-3): 111118.

Ekanayake, I.J., Asiedu, R., 2003. Problems and perspectives of yam-based cropping systems in Africa. Journal of Crop Production 9 (1-2): 531-558.

FAO, 2014. FAO Statistical Yearbook: Africa Food and Agriculture. Food and Agriculture Organization of the United Nation, Regional Office for Africa, Accra. Available at [access date: 03.07.2017]: http://www.fao.org/3/ai3620e.pdf

Giovannetti, M., Mosse, B., 1980. An evaluation of techniques for measuring vesicular arbuscular mycorrhizal infection in roots. New Phytologist 84(3): 489-500.

Hart, M., Ehret, D.L., Krumbein, A., Leung, C., Murch, S., Turi, C., Franken, P., 2014. Inoculation with arbuscular mycorrhizal fungi improves the nutritional value of tomatoes. Mycorrhiza 25(5): 359-376.

Hol, W.H.G., Cook, R., 2005. An overview of arbuscular mycorrhizal fungi-nematode interactions. Basic and Applied Ecology 6(6): 489-503.

Hussey, R.S., Barker, K.R., 1973. A comparison of methods of collecting inocula of Meloidogyne spp. including a new technique. Plant Disease Reporter 57: 1925-1928.

Kolawole, G.O., 2013. Effects of leguminous plant residues and NPK fertilizer application on the performance of yam (Dioscorea rotundata 'c.v.' ewuru) in south-western Nigeria. Archives of Soil Science and Agronomy 59(3): 424434.

Kolawole, G.O., Adeleke, A.R., Ogunrinde, J.O., 2015. Effect of phosphorus fertilizer and mycorrhizal on the performances of soybean and cowpea in a pot experiment. Proceedings of the 39th Annual Conferences of Soil Science Society of Nigeria. $9^{\text {th }}-13^{\text {th }}$ March 2015. pp. $231-238$.

Kwoseh, C.K., 2000. Identification of resistance to major nematode pests of yams (Dioscorea spp.) in West Africa. University of Reading, Reading, UK. PhD Thesis, 175 pp.

Liu, W., Zhang, Y., Jiang, S., Deng, Y., Christie, P., Murray, P.J., Li, X., Zhang, J., 2016. Arbuscular mycorrhizal fungi in soil and roots respond differently to phosphorus inputs in an intensively managed calcareous agricultural soil. Scientific Reports 6: 24902.

Mekete, T., Dababat, A.A., Sekora, N., Akyazi, F., Abebe, E., 2012. Identification key for agriculturally important plantparasitic nematodes. International Nematode Diagnosis and Identification Course 2012 - A manual for nematology. Mexico, D. F. CIMMYT. Available at [access date: 03.07.2017]: http://nematologia.com.br/wpcontent/uploads/2013/07/nemkeymex.pdf

Odoh, N.C., Oluwasemire, K.O., 2015. Evaluation of mycorrhizae potentials in enhancing the growth and yield of Dioscorea rotundata genotypes in moisture stressed soil. International Journal of Agriculture Innovations and Research 4(3): $475-481$.

Okoli, O.N., Onwueme, I.C., 1986. Yam and the Africa food crisis in Tropical root crops. In: Tropical Root Crops and the African food crisis. Terry, E.R., Akoroda, M.O., Arene, O.B., (Eds.). Proceedings of the third Triennial Symposium of The International Society for ropical Root Crops -Africa Branch held in Owerri, Nigeria, 17-23 August 1986. pp. 38-42. 
SAS Institute Staff. 2009. SAS users guide: statistics. Cary (NC): SAS Institute Inc.

Sasser, J.N., Carter, C.C., Hartman, K.N., 1984. Standardization of host suitability studies and reporting of resistance to root-knot nematodes. A cooperative publication of the North Carolina State University, Department of plant pathology and USAID. Raleigh, North Carolina, USA. Available at [access date: 03.07.2017]: http://pdf.usaid.gov/pdf_docs/PNAAR709.pdf

Sidibe, D., Fofana, I.J., Silue, S., Diarrassouba, N., Adolphe, Z., Nguetta, S.P.A., 2015. Evaluation of symbiosis effect of some arbuscular mycorrhizal fungi on growth of yams (Dioscorea Alata) on experimental conditions. Research Journal of Pharmaceutical, Biological and Chemical Sciences 3 (3): 346-357.

Sylvia, D.M., Schenck, N.C., 1983. Application of superphosphate to mycorrhizal plants stimulates sporulation of phosphorus tolerant vesicular-arbuscular mycorrhizal fungi. New Phytology 95(4): 655-661.

Tchabi, A., Hountondji, F.C., Ogunsola, B., Lawouin, L., Coyne, D., Wiemken, A., Oehl, F. (2016). Effect of two species of arbuscular mycorrhizal fungi inoculation on development of micro-propagated yam plantlets and suppression of Scutellonema bradys (Tylenchideae). Journal of Entomology and Nematology 8(1): 1-10.

Vivekanandan, M., Fixen, P.E., 1991. Cropping systems effects on mycorrhizal colonization, early growth, and phosphorus uptake of corn. Soil Science Society of America Journal 55(1): 136-140.

Whitehead, A.G., Hemming, J.R., 1965. A comparison of some quantitative methods of extracting small vermiform nematodes from soil. Annals of Applied Biology 55(1): 25-38. 